\title{
カタボライト活性化タンパク質と 環状AMP複合体の構造解析
}

\author{
薄木 亮、仙石康雄 ${ }^{1} 、$ 松岡 誠、田中成典 ${ }^{2} 、$ 栗田典之 ${ }^{1 *}$ \\ ${ }^{1}$ 豊橋技術科学大学、知識情報工学系、 $\bar{T} 441-8580$ 愛知県豊橋市天伯町雲雀ヶ丘1-1 \\ 2 神戶大学大学院、自然科学研究科、地球惑星システム科学専攻、 \\ 于 657-8501 神戶市灘区六甲台町1-1
}

(Received March 4, 2004; Accepted June 15, 2004)

\begin{abstract}
カタボライト活性化タンパク質 (Catabolite Activator Protein:CAP)は、環状AMP(cAMP)と結合 しCAP-cAMP複合体となりDNAの特定部位に結合し、RNAポリメラーゼのDNAへの結合を促進 する。光の結果、DNAからRNAへの遺伝情報の転写が促進される。我々は、この機構を明らか にする目的で、AMBER力場を用い、CAP-cAMP複合体、CAP単体、CAP-cGMP複合体の安定構 造を解析した。弚の結果を基に、CAPの2量体へのcAMP結合により、CAPの構造(特に2量体間の 相対位置)がどのように変化するかを明らかにした。さらに、cAMPの代わりに、cGMPが結合し た場合の構造変化を解析し、何故、cAMPのみが、CAPのDNAへの結合能を増大させるのかを検 討した。
\end{abstract}

キーワード：転写活性タンパク質、環状AMP、CAP、AMBER力場、安定構造、分子力場計算

\footnotetext{
*kurita@cochem2.tutkie.tut.ac.jp
} 


\section{1. 研究背景}

ポストゲノムの研究において、DNA遺伝情報がタ ンパク質に転写される機構の解明は重要な役割を持 つている。転写活性タンパク質のひとつであるカタ ボライト活性化タンパク質CAP(Catabolite Activator Protein)は、ATP由来のヌクレオチドである環状 AMP(cAMP) と結合しCAP-cAMP複合体となり、DNA の特定部位に結合する。CAP-cAMPが結合した部位 がターゲットとなり、RNAポリメラーゼかDNAに結 合しやすくなり、光の結果、DNAからRNAへの遺伝 情報の転写が促進される。この調節機構は次のよう に起こると考えられている[1]。

(1) アデニル酸シクラーゼを阻害するグルコースの 減少によって、アデニル酸シクラーゼが活性化 される。

(2) アデニル酸シクラーゼを触媒としてアデノシン シリン酸(ATP)がcAMPに変化し、cAMPの量が 増加する。

(3) cAMPがCAPに結合し、CAP-cAMP複合体となる。

(4) この複合体は、CAP単体と比べて、DNAとの結 合が容易であり、CAP-cAMPとDNAの結合が促 進される。

(5) CAP-cAMPが結合したDNA部位をターゲットに して、RNAポリメラーゼがDNAに結合しやすく なり、ラクトースオペロンの転写が促進される。

しかし、(4)のCAP-cAMP複合体がDNAに結合しや すくなり、転写を促進する原因は未だ解明されてい ない。またcAMPの代わりにcGMPをCAPと結合させ た場合、CAPのDNAへの結合能はcAMPに比べて低 いことが分かっている。

本研究では、CAPの2量体へのcAMP結合により、 CAPの構造がどのように変化するかを分子力場 AMBERを用いた分子力場 $(M M)$ 計算により明らかに した。また、cGMPが結合した場合の構造変化を解 析し、cAMPとcGMPがCAPに及ぼす影響の相違につ いて検討した。

\section{2. 計算方法}

\subsection{CAP、CAP-cAMP複合体、CAP-cGMP 複合体の構造作成}

Protein Data Bank(PDB)に登録されている CAP-cAMPの構造(PDBコード : 1G6N[1])を利用した。 この構造はCAPの2量体を含む。片方のCAPは201残
基、もう片方のCAPは200残基から構成され、2量体 の対称性が失われているので、不足する Glyを分子設 計支援システムHyperChem[2]で追加し、末端処理を 行った。乥して追加部分のみAMBER力場[3]を用い て、構造最適化した。また、cAMPのアデニン基を グアニン基に置換したcGMP構造に置き換え、 CAP-cGMP複合体の構造を作成した。

\subsection{AMBER用のパラメータファイルの作 成}

汎用のMM/MDプログラムTINKER[4]のAMBER 力場[3]用のパラメータファイルには、アミノ酸用の データは含まれているが、cAMPやcGMPのデータは 含まれていない。弚こで、非経験的分子軌道計算プ ログラムGaussian98 (G98)[5]を用い、Restrained Electrostatic Potential (RESP)計算[6]を行うことによ り電荷分布を求め、AMBER用のパラメータファイ ルを作成した。

\subsection{AMBERによるMM計算}

CAP単体、CAP-cAMP複合体、CAP-cGMP複合体 に対して、2.1.で作成した構造を初期構造にして、 TINKERのminimizeコマンドを用いて、GNORM $=0.1$ まで構造最適化を行った。关の際、PDB構造 (1G6N[1])に含まれる結晶水及び溶媒水の影響を明 らかにする目的で、以下の6種類の計算条件で CAP-cAMP構造を最適化し、PDB構造を最も再現す る計算条件を決定した。光の計算条件の下で、CAP 単体及びCAP-cGMPの構造を求めた。

(1) 真空中、結晶水なし

(2) 真空中、結晶水あり

(3) 一樣溶媒、結晶水なし

(4) 一樣溶媒、結晶水あり

（5）水球中、結晶水なし

（6）水球中、結晶水あり

一樣溶媒については、TINKERのsolvateキーワードを 用い、Still法[7]で計算した。また、富士ゼロックス 社が開発したTINKER用水球付加プログラム Mkwatball[8]を使用し、CAP-cAMPのまわりにTIP3P 力場に基づいて半径 $42 \AA ̊ 丿$ の水分子を配置させ、水球 中の構造を作成した。また、HyperChem[2]における 標準のHisアミノ酸は電荷が+1なので、この水素を一 つ除いて中性にした中性のHisで同樣の計算を行っ た。 


\section{3. 結果と考察}

\section{1. 計算手法の精度の検証}

CAP-cAMP複合体に対して上記の6種類の計算条 件で、構造最適化を行い、光の構造とPDB構造との 比較を行った。

Fig.1a〜cにPDB構造(黑)、真空中(赤)、一樣溶媒(青)、 水球中(緑)の構造をTINKERのプログラムsuperpose を使用し重心を合わせた後に、WebLab Viewer[9]を 使用して重ねた図を示す。これらの構造のうち、真 空中の構造のみ大幅にずれているところが、数箇所 あることが分かる。特に、CAP-cAMP複合体表面に 存在する原子の位置が大きくずれており、真空中で の構造最適化ではCAP-cAMPのPDB構造を十分に記 述できないことが明らかになった。一方、一樣溶媒 及び水球中の構造は、真空中の構造に比べてPDB構 造からのずれは全体的に小さい。また、Fig.1a、1b、 1cの比較から、PDB中の結晶水及びHisの電荷による 真空中、一樣溶媒、水球中の比較に対して影響は大 きくないことが明らかになった。

各最適化構造についてPDB構造からのずれを各原 子ごとに求めた $(\mathrm{Fig} .2 \mathrm{a} \sim \mathrm{c})$ 。真空中では最大で9〜 11 ^ももずれている原子が見つかった。Hisの電荷、結晶 水の有無に関わらず、片側のCAPの94番目の残基で あるLysの部分で最も大きくずれている。また、一樣 溶媒、水球中では4Å 以上のずれは存在せず、計算条 件によってずれが大きい部分が変わっている。一樣 溶媒ではC末端及び14番目のIleで、水球中では12番 目のCys、105番目のAspで4̊̊近くずれている。

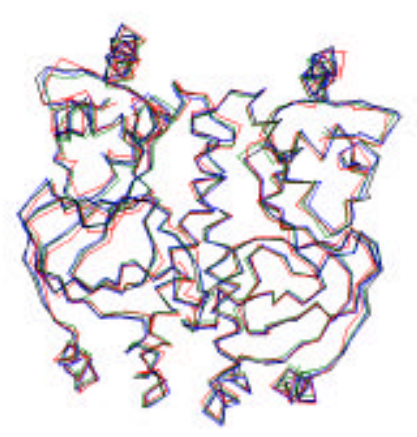

(a) His+, without crystal water

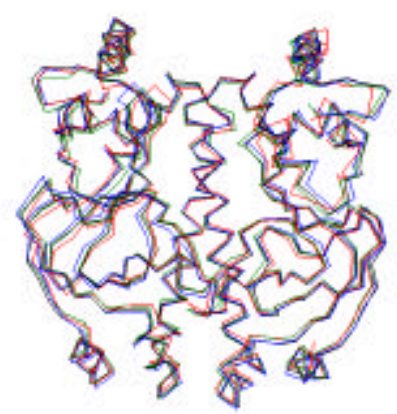

(b) His+, with crystal waters

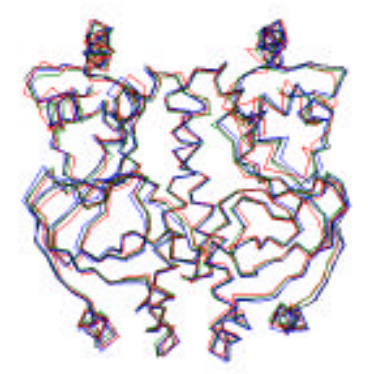

(c) His, with crystal waters

Figure 1. Structures of CAP-cAMP complex: PDB structure (yellow), optimized in vacuum (red), optimized in a uniform solvation (blue) and optimized in solvated waters (green). 


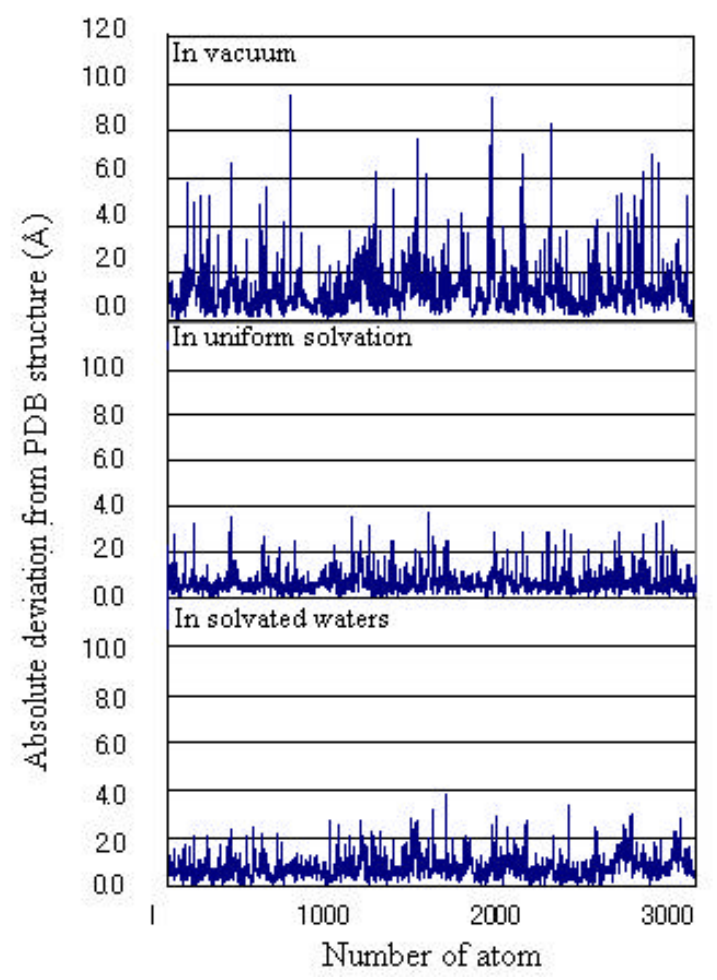

(a) His+, without crystal water

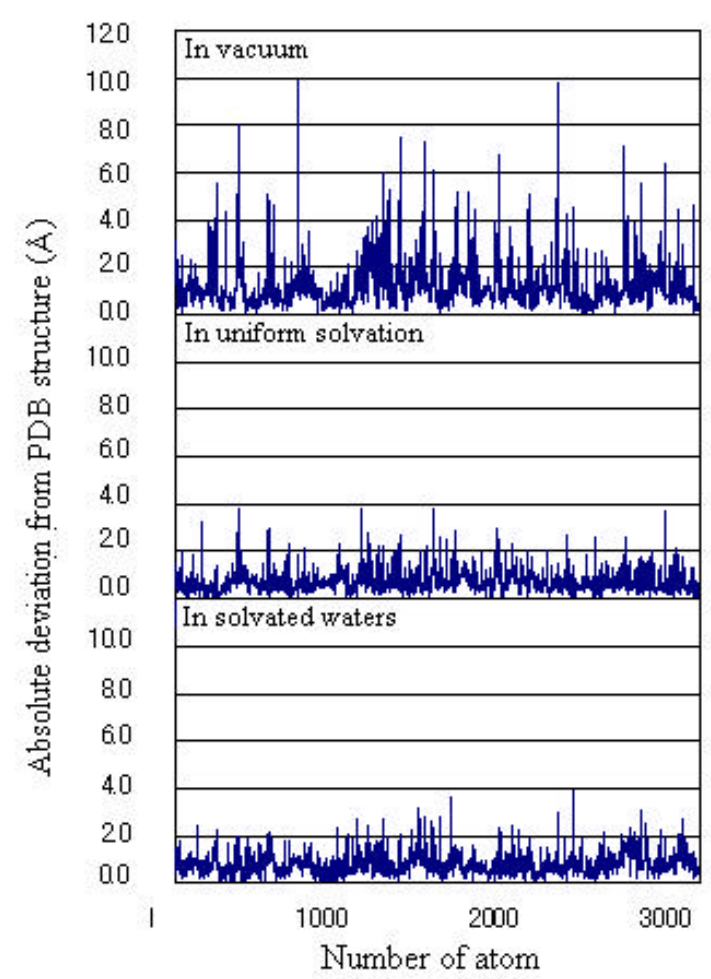

(b) His+, with crystal waters

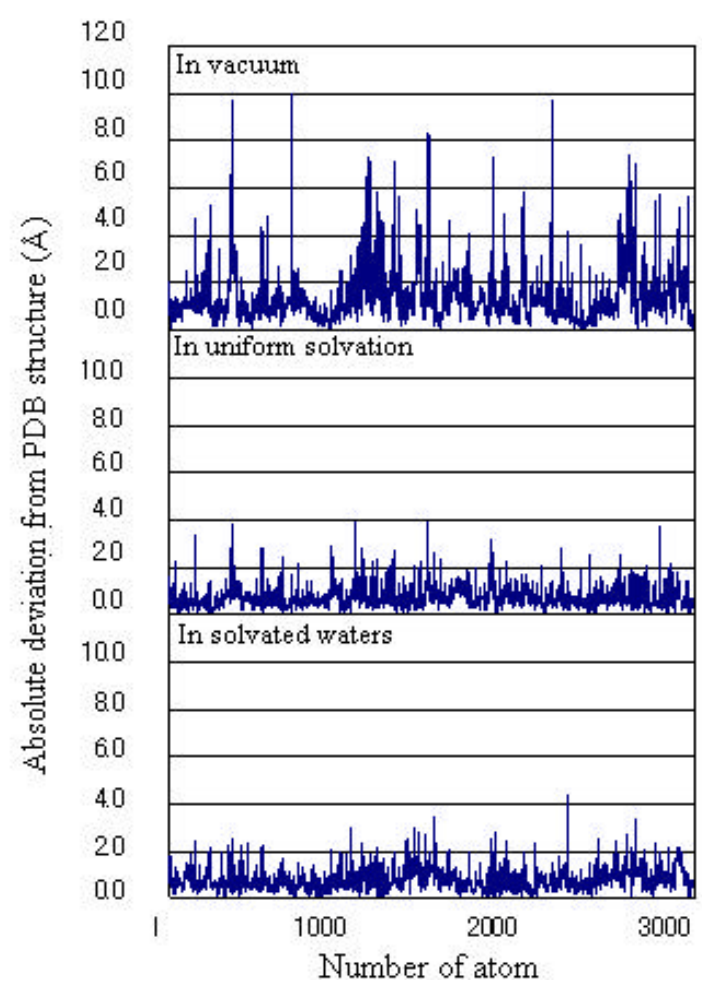

(b) His, with crystal waters

Figure 2. Deviations ( $\AA$ ) from PDB structure (1G6N[1]) of CAP-cAMP complex.

さらに、PDB構造とのずれの大きさを定量的に調 べるためRoot Mean Square Deviation (RMSD)を求め た(Table 1)。真空中で最適化した構造に関しては RMSDが1Å以上になり、十分な精度が得られていな い。一方、一樣溶媒近似でのRMSDの大きさが、水 球中での值よりわずかに小さくなっている。また、 これらのPDB構造からのずれは $1 \AA$ 以下であり、一樣 溶媒近似でも、PDB構造と比較できる構造が得られ ていると言える。

Table 1. Root Mean Square Deviations (Å) of the Optimized Structures from the PDB Structure (1G6N[1]) for CAP-cAMP Complex

\begin{tabular}{|c|c|c|c|}
\hline & $\begin{array}{c}\text { His+ } \\
\text { without } \\
\text { crystal } \\
\text { water }\end{array}$ & $\begin{array}{c}\text { His+ } \\
\text { with } \\
\text { crystal } \\
\text { waters }\end{array}$ & $\begin{array}{c}\text { His } \\
\text { with } \\
\text { crystal } \\
\text { waters }\end{array}$ \\
\hline In vacuum & 1.59 & 1.50 & 1.71 \\
\hline In uniform solvation & 0.74 & 0.82 & 0.82 \\
\hline In solvated waters & 0.88 & 0.86 & 0.89 \\
\hline
\end{tabular}


次に、CAP主鎖の2面角について、PDB構造からの ずれを比較した(Table 2)。真空中の計算では、2面角 のずれが1.2度以上あるが、一樣溶媒近似の計算では ずれが0.7度以下になり、水球付加した計算では 0.8 〜1.0度となり、一樣溶媒及び水球中では良い結果が でている。これらのことを考慮して、CAPに対する リガンドの影響を比較するために一樣溶媒近似を使 用する。また、Hisの電荷を中性とした場合及び+1 電荷を持つとした場合で、RMSD及び面角に大きな 差は出ていないので、以下の計算では、中性のHis を選択した。

Table 2. Root Mean Square Deviations of Dihedral Angle (degree) from the PDB Structure (1G6N[1]) for CAP-cAMP Complex

\begin{tabular}{|c|c|c|c|}
\hline & $\begin{array}{c}\text { His+ } \\
\text { without } \\
\text { crystal } \\
\text { water }\end{array}$ & $\begin{array}{c}\text { His+ } \\
\text { with } \\
\text { crystal } \\
\text { waters }\end{array}$ & $\begin{array}{c}\text { His } \\
\text { with } \\
\text { crystal } \\
\text { waters }\end{array}$ \\
\hline In vacuum & 1.429 & 1.243 & 1.234 \\
\hline In uniform solvation & 0.670 & 0.668 & 0.669 \\
\hline In solvated waters & 0.917 & 0.813 & 0.831 \\
\hline
\end{tabular}

\subsection{CAP-cAMP、CAP、CAP-cGMPの最適 化構造の比較}

3.1.より一樣溶媒近似での計算で、CAP-cAMP複合 体のPDB構造が十分な精度で得られることが明らか になったので、同じ計算条件(His 中性、結晶水あり) でCAP単体、CAP-cGMPの構造を求め、構造を比較 した。CAP単体の構造を基準にして、CAP-cAMP及

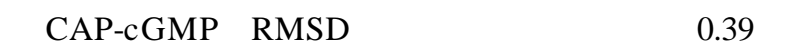
$0.29 \AA$ となる。従って、CAPの構造に対するcAMP付 加の影響は、cGMP付加に比へてて大いことが明ら かになった。

Figure 3にこれらの構造を重ね合わせた図を示す。 CAPと比較するとCAP-cAMPに大きなずれが数箇所 あるのが分かる。Figure 4a、4bに原子ごとのCAP単 体構造からのずれを示す。CAP-cAMPの大きなずれ があった部分は、C末端、143番のAsn、49番のGluの 3箇所で、3.8〜4.0Åのずれがあった。

次にcAMP及びcGMP付加により、CAPの2量体間 の相対位置がどのように変化するかを明らかにする ために、CAP、CAP-cAMP、CAP-cGMPについて各 単量体間の重心距離を求めた。光の結果、25.13

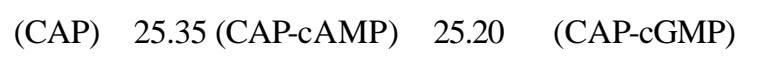
なり、cAMP付加により、CAPの2量体間の距離が 0.22 Å 大きくなることが明らかになった。一方、cGMP 付加の影響は、0.07Å であり、cAMPよりも小さいこ とが明らかになった。結合部位と考えられるcAMP
及びcGMPのOと光の原子に最も近いArgの先端のN との距離と比較すると、2量体乥れ光れのリガンドに

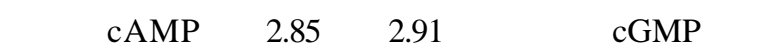
$2.82 \AA ̊ 2.88 \AA ̊$ となった。従って、CAP-cAMPの結合 により構造変化が起こり、実験で示されているとお りcAMPが結合したときのみCAPとDNAとの結合能

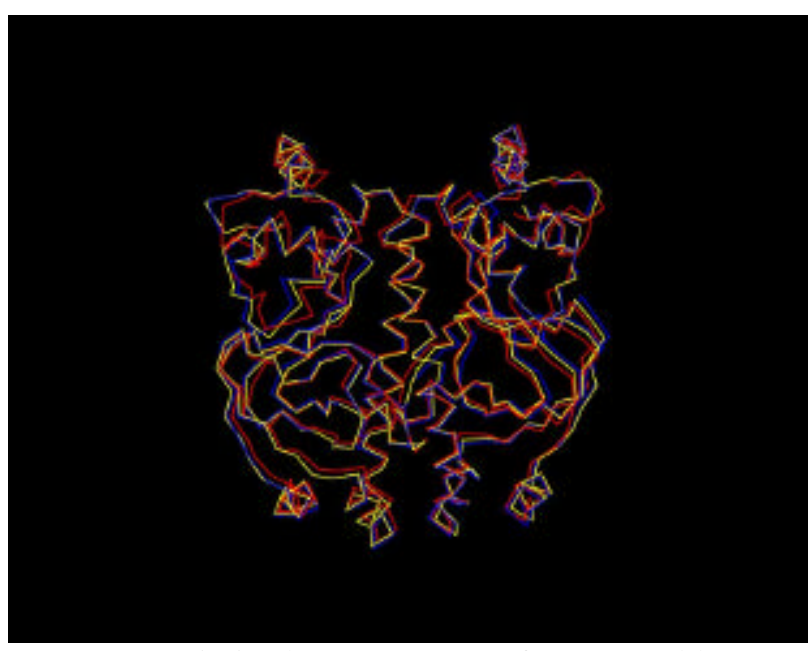

Figure 3. Optimized structures of CAP (blue), CAP-cAMP (red) and CAP-cGMP (green) in the uniform solvation model by Still [7].

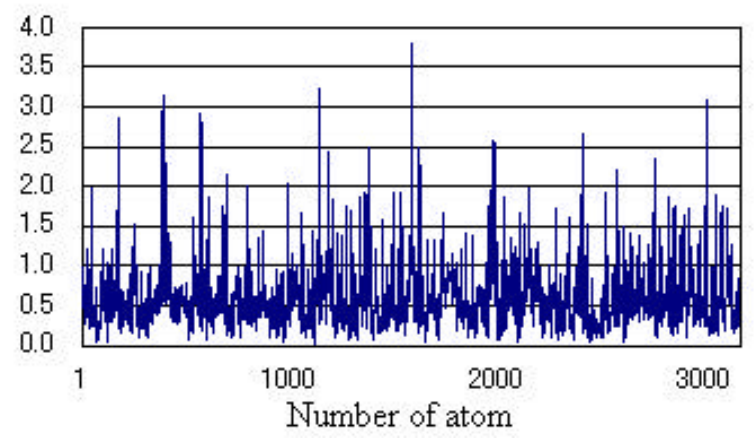

(a) Deviations $(\AA)$ of CAP-cAMP from CAP

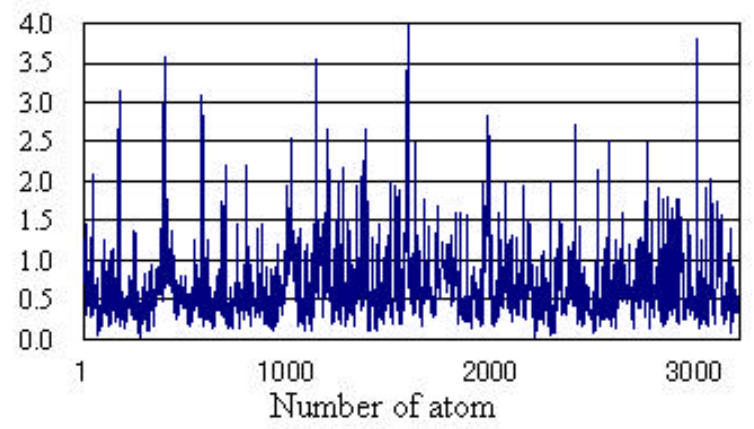

(b) Deviations $(\AA)$ of CAP-cGMP from CAP Figure 4. Deviations of (a) CAP-cAMP and (b) CAP-cGMP structures from the CAP structure obtained by the uniform solvation model. 
に影響を及ぼす可能性があると指摘できる。今後、 室温における分子動力学計算を行い、CAP単体、 CAP-cAMP、CAP-cGMPの安定構造をより広い範囲 で探索し、cAMP及びcGMP付加の影響を明らかにす る予定である。

\section{4. 結論}

カタボライト活性タンパク質CAPへのcAMP及び cGMP付加の影響を明らかにするために、AMBER力 場を用いた分子力場(MM)計算により、CAP2量体、 CAP-cAMP、CAP-cGMP複合体の安定構造を求めた。 そ結果、cAMP付加によりcGMPを付加した場合よ り構造が大きく変わり、CAPの各単量体間の距離が 増加した。よって、cAMP付加の影響は、cGMP付加 の影響よりも大きく、実験結果と定性的に一致する 結果が得られた。

今後、定量性や計算条件の面で精度を上げるため、 分子動力学計算により大域的に安定構造を探索し、 CAMP及びcGIPの影響を調べ、従来のモデルの妥当性 を原子レベルで明らかにする。

本研究は、科学技術振興事業団の計算科学技術活 用型特定研究開発推進事業の助成金、及び日本学術 振興会の科学研究費補助金 (基盤研究(B)、

№. 15310088) を受けて行われた。

\section{文献および注}

[1] J. M. Passner, S. C. Schultz, and T. A. Steitz, J. Mol. Biol., 304, 847 (2000).

[2] HyperChem 6.03, Hyper Cube Inc., Florida,USA (2000).

[3] W. D. Cornell, P. Cieplak, C. I. Bayly, I. R. Gould, K. M. Merz, Jr., D. M. Ferguson, D. C. Spellmeyer, T. Fox, J. W. Caldwell, P. A. Kollman, J. Am. Chem. Soc., 117, 5179 (1995).

[4] TINKER 3.9, Jay William Ponder, http://dasher.wustl.edu/tinker/, (1990).

[5] M. J Frisch et al., Gaussian98 (Revision A.1) Gaussian Inc., Pittsburgh, PA, USA (1998).

[6] P. Cieplak, W. D. Cornell, C. Bayly, P. A. Kollman, J. Comp. Chem. 161357 (1995).

[7] D. Qiu, P. S. Shenkin, F. P. Hollinger and W. C. Still, J. Phys. Chem. A, 101, 3005-3014 (1997).

[8] Mkwatball, Fuji Xerox Co., http://www.fujixerox.co.jp/nbc/esradd/MDEngineII /indexe.html

[9] Accelrys Inc., http://bio.nagaokaut.ac.jp/ 


\title{
Stable Structure for the Complex of Catabolite Activator Protein and Cyclic AMP: Molecular Mechanics Optimization by AMBER
}

\author{
Ryo Usuki ${ }^{1}$, Yasuo Sengoku ${ }^{1}$, Makoto Matsuoka ${ }^{1}$, Shigenori Tanaka ${ }^{2}$, \\ Noriyuki Kurita ${ }^{1} *$
}

\author{
${ }^{1}$ Toyohashi University of Technology, Knowledge-based Information Engineering, \\ 1-1 Hibarigaoka, Tempaku-cho, Toyohashi, 441-8580, Japan \\ ${ }^{2}$ Graduate School of Science and Technology, Kobe Universityorporate, \\ 1-1, Rokkodai, Nada, Kobe 657-8501, Japan
}

\begin{abstract}
To elucidate the effect of cyclic AMP and cyclic GMP addition to the catabolite activator protein (CAP) on its complex structure, we investigated the stable structures of CAP dimer, CAP-cAMP and CAP-cGMP complexes by the molecular mechanics calculations using the AMBER Force Field. The cAMP addition is found to have rather large effect on the CAP dimer structure compared with that by the cGMP addition. This finding is qualitatively consistent with the experimental result that only cAMP has an effect on enhancing the affinity between CAP and DNA, while cGMP does not.
\end{abstract}

keywords: catabolite activator protein (CAP), cyclic AMP, AMBER force field, structure optimization, molecular mechanics, stable structure

\footnotetext{
*kurita@cochem2.tutkie.tut.ac.jp
} 